\title{
Carnival in the Old World and the New
}

Two remarkable studies of the European Carnival were published just over thirty years ago, in 1965. Julio Caro Baroja's El Carnaval has a distinguished place in the long series of studies in which the author constructed a historical anthropology of Spanish culture. It is rich in local and historical detail. It concentrates on the age of Philip IV, but continues the story into the nineteenth and twentieth centuries, a period of decline which he explained in terms of the secularization of modern society and of "laicismo burocráticon. The author drew on anthropological theory, notably that of Sir James Frazer, but usually to criticize it for speculation and overemphasis on pagan survivals, vestigios or supervivencias ${ }^{1}$.

At the same time, at the other end of Europe, a Russian literary theorist, Mikhail Bakhtin, published a book on Rabelais and the culture of his time which drew parallels between the festive world of Gargantua and Pantagruel and that of popular festivals in sixteenth-century France, Carnival in particular. He too criticized Frazer and the folklorists, but from a rather different point of view, accusing them of a lack of "theoretical pathos", of collecting "curiosities" but failing to see the world of folk humour as a whole ${ }^{2}$.

\section{THEORIES OF CARNIVAL}

What then is the meaning of Carnival? Historians, folklorists and anthropologists have offered three main interpretations of this festival.

In the first place, Carnival is viewed as essentially an agrarian fertility rite dating from pagan times. Supporters of this view point to common phallic symbols such as long noses, sausages and cocks and to the recurrent figure of the hairy "wild man" ${ }^{3}$. Appropriately enough for a spring festival, Carnival was a ritual of rejuvenation in which young people played

1 Julio Caro Baroja, El Carnaval (Madrid, 1965), especially 21, 63ff, 126, 265.

2 Mikhail BAKHTIN, Tvorchestvo Fransua Rable (Moscow, 1965; English translation, Rabelais and bis World, Cambridge, Mass., 1968), especially 54.

3 BAKHTIN (1965), 86, 184n, 191, 316. 
a prominent role and the Fountain of Youth was a recurrent symbol (as in Nuremberg in 1510). Such was in essence the view of Sir James Frazer (who interpreted the cock as a vegetation spirit), as it was of the German folklorist Wilhelm Mannhardt, another scholar criticized by Don Julio. Bakhtin too pointed to links between athe slinging of excrement and drenching in urine" in carnival and the themes of fertility and renewal ${ }^{4}$. The "pagan" interpretation still has its adherents. The French folklorist Claude Gaignebet, for example, goes so far as to describe Carnival as itself a religion, going back to pre-christian times, in which the cult of the moon plays an important roles.

For others, Carnival is a fundamentally christian ritual. As Caro Baroja put it, the traditional representation of Lent in particular está tan en concordancia con el espíritu medieval cristiano europeo, que convertirla en una supervivencia más es quitarle la mayor parte de su fuerza expresiva " ${ }^{6}$. As the British historian John Bossy has argued more recently, "The object of the feast was... to bring the corpus of sin to light, in order that it might be got rid of in time for Lent" ${ }^{7}$. Bossy supports his argument with the observation that proceedings often terminated with the trial and execution of Carnival in the form of an image of a fat man. According to this view, the emphasis on meat, drink and sexual activity during the time of carnival is to be explained by the need to abstain from them in the period which followed. The German and Dutch names for the festival (Fastnacht, Vastenavond, in other words the night before the fast) also suggest that the meaning of carnival derives from its juxtaposition and opposition to Lent.

Yet other scholars interpret Carnival as an enactment of the "world turned upside down", in which what is normally forbidden is permissible, indeed compulsory. They note that the festival was associated not only with food drink and sex, but also with speaking one's mind and criticising one's neighbour or the authorities or society in general. The feast was thus a safety-valve permitting society to function in a more or less orderly manner for the rest of the year -though the valve did not always function and carnival violence sometimes turned into riot, revolt (as in Basel in 1529), or even massacre, as in Pordenone in Friuli in 1511 and Romans in Dauphiné in $1580^{\circ}$. Don Julio too notes the place of violence

4 BAKHTIN (1965), 148-9.

5 Claude GaIGNEBET, Le carnaval (Paris, 1974).

6 Caro Baroja (1965), 22, 126.

7 John Bossy, Christianity in the West, 1400-1700 (Oxford, 1985).

8 Peter WeIDKUHN, "Carnival in Basel", Cultures, 3 (1976), 29-52; Edward MuIR, Mad Blood Stirring (Baltimore, 1993); Emmanuel LE ROY LADURIE, Carnaval (Paris, 1979). 
in Carnival - the persecution of animals, the licence to insult and the criticism of the authorities, just as he notes the inversions of the normal order of things ${ }^{9}$. However, it is Bakhtin who places most emphasis on the elements of inversion, social criticism and of festive violence, which he links to Rabelais's frequent and joyous descriptions of beatings ${ }^{10}$.

Not only the christian interpretation of Carnival but the two rival views had their equivalents in the sixteenth century. Reformers, the Bavarian Lutheran Thomas Naogeorgus for example, frequently asserted that Carnival was a survival of the pagan Saturnalia and Bacchanalia. On the other hand, defenders of Carnival, like Folly in Erasmus's Moriae Encomium (1511), argued that human beings need a time to laugh (though Erasmus himself was not amused when he encountered a carnival on his visit to Italy).

Faced with this diversity of interpretations, what should we do? In my view (and, I believe, in Caro Baroja's too), it would be a mistake to adopt a single monolithic view of Carnival. The festival was Protean, appealing to different people for different reasons. Some interpretations work better at a conscious level, like Carnival as a preparation for Lent; others are probably examples of unconscious symbolism, like throwing dung as a fertility rite. What is more, different meanings may have been dominant in different places and times. It is necessary to consider the social history of Carnival. Caro Baroja, for instance, noted the urbanization of Carnival in its age of decline. "Del siglo 18 al 19, el Carnaval urbano ganó importancia pero perdio fuerza" ${ }^{11}$. Again, in the case of western Europe in the sixteenth and seventeenth centuries, it is possible to detect a withdrawal of the upper classes, who increasingly preferred to celebrate by themselves within their palaces, rather than rejoicing in the streets with everyone else.

Thus changes in the festival reflect not only what the sociologist Norbert Elias called the "process of civilization" (in other words, increasing selfcontrol), but also what Bakhtin called the decline, degradation or "disintegration" of folk laughter, a process which can be linked to the increasing social and cultural distance between the elites and the people ${ }^{12}$. In order to take this social analysis of Carnival a little further, and to illustrate the diversity of its forms in different contexts, the remainder of this article will discuss the transplantation of Carnival, its history in the New World.

9 CARO BAROJA (1965), 53ff, 83ff, 90ff, 146, 209.

10 BAKHTIN (1965), 81ff, 89, $199 \mathrm{ff}$.

11 CARO Baroja (1965), 147.

12 Peter BuRKE, Popular Culture in Early Modern Europe (London, 1978); Norbert ElIAS, The Civilizing Process (1939; English translation Oxford, 1978-82); BAKHTIN (1965), $67,72,101,115$. 


\section{CARNIVAL IN THE NEW WORLD}

Like other European institutions the Carnival, with all its ambiguities and ambivalence, was transported to the New World, especially to that part of it which was colonized by Catholics from the Mediterranean. To this day Carnival remains important in the life of New Orleans, Port of Spain and La Habana as well as in Rio and Recife, thanks to the influence of French, Portuguese and Spanish immigrants.

This New World Carnival is much more than a European import. Like so many items of European culture, it has been transformed in the course of its sojourn in the Americas, as three examples will show. In the first place the importance and the active role of women in the carnivals of the Americas contrasts with traditional European customs, in which - despite the practices of cross-dressing - woman's place was generally on the balcony, observing (and sometimes throwing things at the men below), rather than in the street, fully participating. The patriarchal world was not turned completely upside down at this time, despite the many references to el mundo al revés, le monde à l'invers, il mundo alla rovescia, Die Verkebrte Welt, and so on. Indeed, the emphasis on drink and violence in the traditional European carnivals as well as the composition of the carnival societies suggests that they should be interpreted as (among other things), rituals of masculinity. There were other popular festivals in which women were "on top", symbolically dominating men, like the feast of Santa Agueda described by Caro Baroja, but this was not a major theme of the European Carnival ${ }^{13}$.

In the New World, on the other hand, despite the transplantation of patriarchalism, described by Latin American writers from Gilberto Freyre to Gabriel García Márquez, women have long been more visible and more active in Carnival ${ }^{14}$. Thus an English officer in Trinidad in 1826 noted that "A party of ladies, having converted themselves into a party of brigands, assailed me in my quarters" ${ }^{15}$. In Brazil, their participation in the entrudo was noted by foreign visitors such as Henry Koster (1816), John Mawe (1822), and Ferdinand Denis (1837).

13 CARO BAROJA (1965), 371-81; cf. Natalie Z. DAVIS, "Women on Top", in her Society and Culture in Early Modern France (Stanford, 1975), 124-51, especially $138 \mathrm{ff}$.

14 Gilberto FREYRE, Casa Grande e Senzala (Rio, 1933); Gabriel García Márquez, El Otoño del Patiarca.

15 Quoted in Andrew PEARSE, "Carnival in Nineteenth-Century Trinidad", Caribbean Quarterly, 4 (1955-6), 180. 
Today, whether their role is passive or active, whether their function is to be viewed by men or to enact their own fantasies, it is impossible to imagine a Brazilian carnival without an overwhelming female presence including the destaques, or symbolic figures on the floats; the pastoras, or "shepherdesses" dancing in front of or behind the floats; the baianas (women in the traditional costume of Bahia); and the Portabandeira or standard-bearer, whose dance with her male partner the Mestre-sala counts for several points in the competition between samba schools in Rio ${ }^{16}$.

Linked to the more active role of women, the importance of dancing makes the New World carnivals distinctive. Sword-dancing in particualr occurred in traditional European carnivals but the dance did not have the same importance there as (say) in Trinidad, where the calinda or stickdance has been a central part of the festivities from the early nineteenth century at the latest ${ }^{17}$.

These examples are of male dances, but mixed dancing has been important in the Carnivals of the Americas since the nineteenth century. In early nineteenth-century Trinidad, men and women of the planter class danced the belair, the bamboula and the ghouba. The classic instance is that of Brazil, from the age of the polka, the dance dominant form 1850 to 1900 , to that of the maxixe, in the 1870s, and the samba, dominant from 1917 to our own time. In Rio, dancing was a central part of the desfile, the Carnival parade, which became a central part of the festivities from the mid-nineteenth century onwards. Not only the "infantry" accompanying the floats, but many of the women displayed on the floats themselves dance the samba.

Besides dancing in the streets, the Brazilian Carnival has long included balls in private houses, clubs, hotels (starting with the Hotel Itália in Rio in 1840 ), and theatres (such as the Teatro São João in Salvador in the 1860s) ${ }^{18}$. In other parts of Latin America, dancing has also been an important element in Carnival. In Buenos Aires, for example, and in La Habana, where masked balls took place in the Tacón theatre from 1838 onwards ${ }^{19}$.

16 Olga RODRIGUES DE MORAES VON SimSON, "Mulher e Carnaval: mito e realidade", Revista de História, 125-6 (1991-2), 7-32; for the view of a participant observer in Rio, Alma GuIllermoprieto, Samba (New York, 1990); for illustrations, see Monica RECTOR, "The Code and Message of Carnivaln, in Thomas A. Sebeok ed., Carnival! (Berlin, 1984), 37-165.

17 E. HILl, The Trinidad Carnival (London, 1972), 11. On dancing in Basque carnivals, CARO BAROJA (1965), $175 \mathrm{ff}$.

18 Edgar de AlENCAR, O Carnaval Carioca através da musica (second ed. Rio, 1965).

19 A. J. Pérez AMUCHÁstegui, Mentalidades argentinas (eighth ed., Buenos Aires, 1988), 158ff; Fernando ORTIZ, "Los viejos carnavales habaneros" (1954: rpr in his Estudios etnosociológicos, La Habana, 1991), 204. 
Linked in turn to the dance is the place of African elements in the Carnival as in other festivities. The celebration of the feast of Corpus Christi in colonial Brazil, in Minas Gerais, for instance, included allegorical floats and dances by blacks with flags, drums and songs -all elements to be found later on in Brazilian carnivals ${ }^{20}$. The tradition of the cucumbi or "kings of the Congo", the enthronement of black kings and queens in splendid costume on the feast of Our Lady of the Rosary, again in Minas Gerais, was also transferred to Carnival ${ }^{21}$. The transition from the irmandades who organized such festivals to the later carnival societies and samba schools was an easy one. Behind these rituals it is occasionally possible to glimpse elements of African tradition, such as the Nigerian festival of the queen, Damurixá ${ }^{22}$.

Wherever and however they originated, Afro-American elements entered the Carnival. In Rio in 1881, for instance, the allegorical float of the Democráticos, a white carnival society of high status, represented an African prince, Obá. The most popular carnival songs in Rio in 1914 and 1923 betray their African origin by their names: "Caboca de Caxangá" and "Macumba". If we try to escape the "Riocentrism" of the majority of studies of Brazilian Carnival and look instead at Recife or Salvador, the survival or reconstruction of African traditions is even more obvious, although it has been overlaid in the last twenty or thirty years by a movement of are-africanization" linked to black consciousness and black power ${ }^{23}$.

Masks play an important role not only in Carnival but also in West African secret societies, such as the Poro. In Trinidad, one of the traditional Carnival masks, the "Moco Jumbie", can be traced back to religious practices in West Africa ${ }^{24}$. In Cuba, as in the Saturnalia of ancient Rome, the temporary liberty of slaves was central to the festival, which also owed something to the tradition of the Ekuaeansu. The blacks took to the streets of La Habana dressed as congos (again), lucumies, ararás and mandingas ${ }^{25}$.

The dance, whether religious or secular, was probably a more important art-form in traditional Africa than anywhere else. In East Africa, for

20 Affonso Avila (1993), 247.

21 Marlyse MEYER, "Neste Mês do Rosário: Indagações sobre Congos e Congadas" (1989, reprinted in her Caminbos do Imaginário no Brasil (São Paulo, 1993), 161-74.

22 Manuel QUERINO, cited by Risério (1981), 49.

23 Peter FRY, Sérgio CARRARA and Ana Luiza MARTINS-COSTA, "Negros e brancos no Carnaval da Velha República", in João José REIS ed., Escravidão e Invenção da Liberdade (São Paulo, 1988), 232-63; Antonio Risério, Carnaval Ijexá (Salvador, 1981), 13, 17.

24 HiLl (1972), 12.

25 Fernando ORTIZ, "Los viejos carnavales habaneros" (1954, rpr in his Estudios etnosociológicos, La Habana 1991), 210-11. On the Saturnalia, CARO BAROJA (1965), $289 \mathrm{ff}$. 
example, there was the tradition of the ngoma, a dance which often took the form of a "parade" or "march past" by members of different dance associations, in which women played a prominent part. In Mombasa these parades included floats which reminded one British official, remembering them in the 1920s, of "the Carnivals at Nice or at New Orleans" ${ }^{26}$.

In West Africa, more relevant to the Americas since the majority of slaves came from the west, the dance was often closely associated with religious practices. The association was closer than was permitted in Europe, where there has been a long tradition of official hostility to dances in church or on the occasion of religious festivals ${ }^{27}$. Among the Tallensi of West Africa, on the other hand, the anthropologist who knew them best reported that "the dancing-ground is sacred" ${ }^{28}$. The dance was commonly used as a technique of ecstasy. It was a ritual provoking possession of the dancers by spirits or gods, as in the case of the Yoruba in Dahomey and Nigeria. Possession should be analysed, as anthropologists have emphasised, not as hysteria but rather as ritual or even as theatre, with the possessed impersonating their god. Drumming was central in these rituals, as in African culture generally. The drums were considered the voices of the gods, each god being associated with a distinctive rhythm ${ }^{29}$.

Possession cults of this kind continue among blacks in the Americas, from the vodun of Haiti and the santeria of Cuba to the candomble of Brazil (which has particularly close links to Yoruba traditions) ${ }^{30}$. These practices have contributed to American carnivals ${ }^{31}$. The place of drums in these carnivals is central in the cases of the baterias of Rio and the "steel bands" of Trinidad (which replaced traditional drums in the 1930s). The dances of the candomble have been compared by participants with the

26 Terence O. RANGER, Dance and Society in Eastern Africa 1890-1970: the Beni Ngoma (London, 1975), 34, $167 \mathrm{ff}$.

27 E. Louis BACKMAN, Religious Dances in the Christian Church and in Popular Medicine (London, 1952).

28 Meyer FORTES, Religion, Morality and the Person (Cambridge, 1987), 51.

29 Michel LEIRIS, La possession et ses aspects théatraux chez les etbiopiens de Gondar (Paris, 1958); Pierre VeRGER, "Trance and Convention in Nago-Yoruba Spirit Mediumship", in John Beattie and John Middleton eds., Spirit Mediumship and Society in Africa (London, 1969), 50-66.

30 Louis MARS, La crise de possession dans le Vaudou (Port-au-Prince, 1946); Roger BASTIDE, Le candomblé de Babia (Paris, 1958); Margaret THOMPSON DREWAL, "Dancing for Ogun in Yorubaland and in Brazil, in Sandra T. Barnes ed., Africa's Ogun: Old World and New (Bloomington, 1989), 199-234.

31 Fernando ORTIZ, "La transculturación blanca de los tambores de los negros" (1952: repr in his Estudios etnosociológicos, La Habana, 1991), 176-201. 
carnival samba ${ }^{32}$. In Brazil, other religious practices were incorporated in Carnival via the afoxé, a word which means not only a dance by blacks and a musical instrument (a gourd rattle), but also a procession of adepts of candomblé to join a carnival. The Brazilian composer and singer Gilberto Gil tells the story that when he was parading in the Carnival of Salvador with the rest of his afoxé group, he once saw a middle-aged woman cross herself, apparently thinking that she was watching a religious procession ${ }^{33}$.

In the religious rituals described above, women have traditionally played an important part. The Hausa Bori possession cults, for example, were and are controlled by women. The so-called "mother of the saint" (mae de santo, ialorixa) remains a central figure in candomble ${ }^{34}$. The baianas so prominent in the Carnival of Rio today, dignified ladies whirling in their long white dresses are a secular version of the mães do santo, just as the excitement of the Carnival itself is a secular form of religious ecstasy. To reinforce the hypothesis of the connection between African religion and American carnival, it may be added that in Salvador, female spirits called tobosa ("girls") "descended" at Carnival, in other words took possession of worshippers ${ }^{35}$.

In Brazil in particular, Afro-American popular traditions are currently being studied with more attention than before by historians ${ }^{36}$. At the same time they are receiving more emphasis in the carnivals themselves as part of the black consciousness movement. For example, afoxé groups such as the "Sons of Gandhi" (founded in 1949 but revived in the 1970s) play an important role in the Carnival of Salvador ${ }^{37}$. In 1995, the Salvador Carnival focussed on Zumbi, leader of the rebel slave community of Palmares, in order to mark the tercentenary of his death.

Research on African elements in Carnival, like other aspects of black popular culture in colonial and nineteenth century Brazil has scarcely begun ${ }^{38}$. All the same, the elements mentioned above may be sufficient

32 Quoted in Mikelle SMITH OMARI, "Candomblé", in Thomas D. Blakeley et al. eds., Religion in Africa (London, 1994), 135-59 at 136.

33 BASTIDE (1958), 248; RISÉRIO (1981), 12, 52, 55-6.

34 A point emphasized by the American anthropologist Ruth LANDES, The City of Women (New York, 1947).

35 BASTIDE (1958), 194.

36 For example, Bob Slenes of the University of Campinas is concentrating attention on this topic.

37 RISÉRIO (1981), 52ff.

38 Marlyse MEYER, "O Carnaval nos Folguedos Populares Brasileiros" (1987: repr in Caminhos, 1993), 175-226; Raquel SOIHET, Subversão pelo Riso: Reflexões sobre Resistência e Circularidade Cultural no Carnaval Carioca (1890-1945), Tese de Prof. Titular, UFF (1993). 
to launch the hypothesis that New World carnivals are "over-determined", in the sense that they have emerged out of the encounter, attraction, interaction, convergence and finally the more or less complete fusion between two festive traditions, the European and the African (if there was also an Amerindian element in this compound, it is difficult to identify it now). It is as if there was some kind of cultural magnetism involved, an attraction between similar elements in the African and European traditions, just as there is a kind of circularity or reciprocal influence between elite and popular traditions ${ }^{39}$. For example, the mock-combat appears to derive both from the dances associated with the cult of the Yoruba warriorgod Ogun and from the Iberian tradition of representing conflicts between "Moors and Christians" in popular religious dramas or autos ${ }^{40}$. The festivals thus exemplify what the Cuban sociologist Fernando Ortiz, himself an enthusiast for Carnival, called "transculturation", in other words the reciprocal interaction between two cultures, as opposed to "acculturation", in which the influence is oneway ${ }^{41}$.

The parallels between the American and European carnivals are also impressive. The throwing of wax balls full of water, much practised in nineteenth-century Rio, for example, derived from the tradition of the Portuguese entrudo, a tradition with many parallels in the Mediterranean world (Provence, Venice, and so on) ${ }^{42}$. The Escolas de Samba and their predecessors (such as the Democráticos, Tenentes do Diabo, or Fenianos in nineteenth-century Rio), are reminiscent of the "Abbeys of Youth" and other European festive societies. The wearing of fancy dress and masks was a traditional European custom, and some of the favourite American costumes, such as the hussars and harlequins of Rio and the Pierrots and Punchinellos of Trinidad, followed European models. The desfile of the Escolas de Samba in Rio today is reminiscent of the parades and allegorical floats which could already be seen in fifteenth-century Florence and Nuremberg. Even the political references in Brazilian carnivals have their European parallels, from protests against taxation in seventeenth-century Spain to the recent mocking of Craxi in Italy.

What is more, the trajectory of carnivals in the New World over the last two hundred years or so runs parallel to that of European carnivals

\footnotetext{
39 Raquel SOIHET, Subversão pelo Riso: Reflexões sobre Resistência e Circularidade Cultural no Carnaval Carioca (1890-1945), Tese de Prof. Titular, UFF (1993.

40 Thompson Drewal (1989), 225; Caro Baroja (1965), 174.

41 ORTIZ (1952).

42 Sandra L. Graham, House and Street (Cambridge, 1988), 68; CARO BAROJA (1965),
} $57 \mathrm{ff}$ 
between the sixteenth and the nineteenth centuries ${ }^{43}$. There have been four main stages in this process; participation, reform, withdrawal and rediscovery. It must of course be remembered that the sources for the history of Carnival generally offer a vision "from above", in which some activities are scarcely visible, but so far as the upper classes at least are concerned, this model has its uses.

The stage of participation may be illustrated from Trinidad in the early nineteenth century, when (according to an English observer) "High and low, rich and poor, learned and unlearned, all found masking suits for the Carnival", or from the Brazilian emperor Pedro II's enjoyment of the traditional entrudo at Petrópolis, in the mid-nineteenth century.

The stage of reform was reached in Trinidad in the later nineteenth century, when some members of the ruling class went so far as to demand the complete abolition of Carnival ${ }^{44}$. In Brazil, there was a campaign to replace the grosseiro e pernicioso entrudo (as the Jornal de Notícias of Salvador called it in 1884), with something more "rational", "hygienic", and "civilized" on the European model (the Brazilian elite was apparently unaware of the importance of sex and violence in the European carnival tradition). These attempts probably reached their climax in Rio in the age of prefect Francisco Pereira Passos, around the turn of the century, when the carnival parades were transferred from Rua do Ouvidor in the heart of the city to avenues on the periphery where they could be controlled more easily. This attempt coincided with a public health campaign and a reconstruction of the city which provoked resistance and even riots ${ }^{45}$. The language of "civilization" versus "barbarism" expressed masked white fears of the growing "africanization" of Carnival, a fear expressed openly in letters to the Jornal das Noticias of Bahia in the first years of the twentieth century. For it was in the 1890s that black carnival clubs such as the Pândegos de Africa were founded in the city ${ }^{46}$. How successful the reform campaign was it is difficult to say. Maria Isaura Pereira de Queiroz has written of "the domestication of an urban mass" in the Carnival of Rio, but her concern with the central events of the festival needs to be balanced against the evidence for a more traditional and informal carnival in other parts of the city ${ }^{47}$.

43 On the European trajectory, Peter BURKE, Popular Culture in Early Modern Europe (London, 1978; second ed., Aldershot, 1994), 178ff, 207ff, 270ff, 281ff; Maria Isaura Pereira DE QueIroz, «Evolution du Carnaval Latino-Américain», Diogène, 104 (1978), 53-69. A critique of the evolutionary model in MiRANDA PEREIRA (1994), introduction.

44 PEARSE (1955-6), 187.

45 Leonardo Affonso de Miranda Pereira, O Carnaval das Letras (Rio, 1994), 39ff.

46 Quoted in FRY (1988), 236, 253-4.

47 Pereira De QueIroz (1992), 71-116; Alba Zaluar, "O Clóvis", Cadernos do CERU (1978). 
That the reform was less than complete is suggested by the third stage, in other words the withdrawal from public participation on the part of the elites, who now organized their own festivities indoors, a "closed carnival" replacing the old open one. In Trinidad, it was as early as the emancipation of the slaves in 1833 that the white elite "withdrew from public participation" in Carnival, while the blacks "appropriated" it, or at least became more visible, using the festivities to commemorate their emancipation and to mock the whites ${ }^{48}$. In Rio, in the words of the Gazeta de Notícias in 1890, "O carnaval elegante retirou-se para as salas, abandonando as ruas para os pobres diabos" ${ }^{49}$. By contrast, in New Orleans the white clubs or "krewes" still dominate the carnival. The parallel black groups like the "Zulu Aid and Pleasure Club" which once mocked the official festivities have now been incorporated into them ${ }^{50}$.

Brazil, like other parts of the New World, is now living through the fourth stage of the process, that of the rediscovery of popular culture, in particular Afro-American culture, on the part of the elites, including the "re-africanization" of Carnival. Needless to say, this fourth stage is linked to the commercialisation of a festival which has become big business and in which television and record companies as well as tourist agencies are deeply involved. In this respect as in others, modern Rio, for instance, is the heir of nineteenth-century Nice and eighteenth-century Venice. What makes American Carnivals different from European ones is above all the mixture and the interaction of cultures which they put on public display.

PETER BURKE

Emmanuel College. Cambridge.

48 PeARSE (1955-6); Hill (1972), 23, 40, 43, 100.

49 Quoted in Miranda Pereira (1994), 202.

50 Contrast Munro S. EDMONDSON, "Carnival in New Orleans", Caribbean Quarterly, 4 (1955-6), 233-45, with Samuel KINSER, Carnival American Style: Mardi Gras at New Orleans and Mobile (Chicago, 1990), 232-40. 
La bibliografía sobre el carnaval permite distinguir tres interpretaciones diferentes de esta fiesta, ya expuestas en el siglo xvi. El autor, sin embargo, siguiendo a Caro Baroja, se niega a tener que elegir a cualquiera de ellas como la más adecuada. "El festival -escribe- era proteico; atraía a diferentes personas por razones diferentes". Además, ha cambiado en el tiempo y en el espacio. Cuando fue llevado a América por inmigrantes mediterráneos, se transformó como resultado de la transculturación; incorporando, por ejemplo, componentes africanos que no tenía el carnaval europeo. No obstante, su desarrollo en América en los dos últimos siglos ha repetido el que tuvo en Europa entre los siglos XVI y XIX.

There are three distinct, traditional views of Carnival. The author, following Caro Baroja, argues that all three are equally valid. "The festival - he writes- was Protean, appealing to different people for different reasons". Besides, it has changed through time and space. When transferred to the New World by Mediterranean immigrants, it was transformed as the result of transculturation; for instance, by incorporating African components that were absent in the Old World. Nonetheless, the development of the festival in the Americas over the past two centuries has followed the same stages of the European Carnival between the 16th and the 19th centuries. 